\title{
The End of Sri Lanka's Civil War and the Fall of the Liberation Tigers of Tamil Eelam (LTTE): A Critical Analysis of the Contributed Factors to the Defeat of the LTTE
}

\author{
M. M. Fazil ${ }^{1} \&$ M. A. M. Fowsar ${ }^{1}$ \\ ${ }^{1}$ Department of Political Science, South Eastern University of Sri Lanka, Sri Lanka \\ Correspondence: M. M. Fazil, Department of Political Science, South Eastern University of Sri Lanka, Sri Lanka. \\ E-mail: fazrasm@seu.ac.lk
}

Received: September 5, 2020

Accepted: October 9, $2020 \quad$ Online Published: October 13, 2020

doi:10.5539/jpl.v13n4p147

URL: https://doi.org/10.5539/jpl.v13n4p147

\begin{abstract}
Sri Lanka came to the international limelight through the backdrop of its undesirable war against the Liberation Tigers of Tamil Eelam (LTTE) that lasted over three decades. The LTTE was formed as a social force, and then it transformed as a leading armed movement to forward their decades-long quest to set up a Tamil homeland in Sri Lanka. The government ended the LTTE's secessionist struggle in May 2009 after a lengthy and bloody battle. Several national and international factors played a crucial role in ending the civil war sooner. The study used a qualitative method of inquiry to explore the key factors that led to the fall of the LTTE, a vigorous armed movement that attempted to set up a separate state in the Island of Sri Lanka. The findings show that strong political leadership, fortified security forces, implementing sophisticated national security strategies, the split of the LTTE and the global war on terrorism are the major factors that had a significant impact and contributed in the LTTE being defeated in 2009.
\end{abstract}

Keywords: the LTTE, civil war, militant movement, minority

\section{Introduction}

In the post-colonial era of the state of Sri Lanka, the ethnic majority dominated the process and framework laid for framing rules. This served as a key instrument of domination as seen on the societal layers within their territories. They prioritised the Sinhalese majority that enjoyed the benefits of state policies planned and implemented for their benefits and interests. This was a kickback being offered in exchange for electoral benefits by the leading parties such as the United National Party (UNP) and Sri Lanka Freedom Party (SLFP). The mainstream political parties whilst appeasing the majority were discriminatory against the Tamil minorities. This led to a slew of policies such as the Citizenship Act, Sinhala only Act, land policies, university admission policies hurting the minorities. This led them to believe that they are being alienated from mainstream politics and putting their culture on the line of absolute neglect. Thus, the post-colonial legacy of Sri Lanka had an undesirable trajectory (Fazil, 2016; Fowsar, 2020).

A collated movement among the Tamil minority political elites led them to demand autonomy for the north and eastern regions by reconstituting state to accommodate a federal solution. This support shifted from the federal state as a solution to separatism, by demanding a separate state through the mid-1970s because of a stalemate in negotiations and continuous discrimination. This separatism transformed their support into veritable actions by giving rise to the Tamil Eelam state comprising the Northern and Eastern regions, as these were traditional Tamil settlements. Diverting further of these demands led to groups such as the LTTE or known as Tamil Tigers rather chose the armed solution for their demand than dialogue and diplomacy. They challenged the image and related practices of the state of Sri Lanka through the strong social force built through militant doctrine by the LTTE. During the end of the $20^{\text {th }}$ century, this very image was under scrutiny and questioning when the LTTE had scored a massive victory over the state of Sri Lanka in their northern and eastern provinces.

This resulting stalemate where neither party was victorious was changing as the international sentiment after September 9/11 attacks on the US-led both the warring parties to agree on reviving the negotiation process. The Sri Lankan government's outreach towards the state's Tamil minorities to reach a peace settlement with the LTTE involved significant third party negotiations. India and later Norway were mediator or facilitator to the peace 
negotiators. The results were not encouraging to both parties like the Indian and Norwegian interlocutors could not yield results, because of new domestic and international political developments. The punitive actions involved infiltrating the LTTE with international concoctors leading to the eastern wing (led by Colonel Karuna) forming another faction adding new doctrine to the social forces and its affiliation with the state. The change in national and international sentiment and focuses contributed to the decline and eventual failure of the LTTE, which were one among several factors. By examining these factors, the study aims to record the leading factors of the defeat of LTTE in preserving their social structure.

\section{Research Methods}

The key categories to the study were the main stakeholders of the state-minority contestations in Sri Lanka. The study followed qualitative research techniques including texts analysis, focus group discussions, field interviews and limited observations. The qualitative data were collected to further divide the categories into subcategories with interests ranging from collecting most variations recorded in responses meeting to present a diverse perspective. The study was narrowed to selecting key categories such as actors in national and international platforms and covering their stakeholder contestations. The manifestation of different political positions, hierarchal structures, ethnicity, religion and culture observed among the key national or local categories. Multiple methods were used to collect data samples from written documents, joint with at least fifty in-depth qualitative interviews with add-on interviews. This approach preceded collection of qualitative data between the periods 2013 till 2017. The interpretative approaches were used to analyse the qualitative data and interpret the findings of the study.

\section{Results and Discussions}

Among national and international factors that have led to the defeat of the LTTE, centralised leadership, held by Prabhakaran, fracture groups, Karuna's defection are very crucial. The strong political leadership, fortified security forces and its military strategies, the assassination of Indian premier Rajiv Gandhi, eventual spotlight on armed resistance across the world post-Sept/11 and international balance of power in the Indian Ocean region coupled with the LTTE's declining ability to wage urban hybrid warfare.

\subsection{National Factors}

The inadequacies in strategic understanding and centralised leadership of Prabhakaran identified as a key aspect in their decline and eventual defeat. The LTTE borrowed their style of leadership from the $20^{\text {th }}$ century which based on the communist insurgent movements. The hierarchy of the LTTE leadership is of a pyramidal framework where the head was one person for both its political and military wing. By taking decisions or routing them all to one person's decision have led to greater control of their society but have scuttled their promise of freedom and autonomy. Hence, it's not surprising to say if Prabhakaran could have led the LTTE to its pit and demise. His nature of dealing with the Tamil liberation movement and aspects with a heavy-handed approach isolated Prabhakaran from his people he strived to protect till the end. The isolation of Tamils was further inculcated by Prabhakaran's decision to pull back from electoral politics and even forbidding them from voting.

The Sri Lankan government capitalized on the attack by LTTE on IPKF (Indian Peace Keeping Force) and the assassination of Former Indian Prime Minister Rajiv Gandhi and secured India as its strategic partner. The last nail in the coffin was to pursue a military resolution with conventional tactics to secure Tamil Eelam sealed their fate. Prabhakaran maintained a level of brutality in consolidating power and used it to advance his agenda. As the war broke, the realization dawned that the LTTE movement had eroded of its support from people for whom it's fighting. When the group of leaders questioned Prabhakaran, they were silenced or killed for no reason but this (Hashim, 2013).

When the LTTE assumed the mantle of sole representatives of the Tamil Eelam cause, the organization assumed and evolved into a cult with Prabhakaran being the chief of wings reporting to him. With the burden to take decisions on his own, he spent little to no time with promoting the political message of the LTTE to the non-Tamils. This could have earned enough sympathy in the long run. Prabhakaran, too, felt the need to focus more on the military side of the running conflict. These points to his lack of awareness of hybrid warfare and not just look at a bloody resolution backed by bluntness and brutality. His cult personality grew to an extent where people worshipped him, where attempts made to present with a grotesque stature (Hashim, 2013).

The LTTE assassinated any kith and kin who questioned their leader and his legitimacy, which included moderate Tamil minority politicians, their people and their military leaders and by imposing heavy taxes, forced labour, indoctrination of children. There were many incidents of brutal repression in the areas they had controlled. These incidents led their people to distance themselves from the LTTE towards the end of the conflict to an extent where even the Tamils provided information to the Sri Lankan military (De Votta, 2009). Prabhakaran established military, 
political and intelligent wings second in command to him, and appointed Karuna as a second hierarchy to the major part of Eastern Province. But, these actions did not prevent Karuna's eventual defection, which was because of the ultimate centralisation of power stoking unrest and displeasure.

"The LTTE's hierarchal and organisational structure faced a lot of unexpected defections. Vinayagamoorthy Muralitharan aka Colonel Karuna Amman, a strategic thinker and contributor to the movement, also the eastern command head, was a close confidante of Prabhakaran. He had a long, storied history with the organisation and had fought for its cause from the age of 12. For 20 years, he served as the commander for Batticaloa and Ampara Region. Along with a cadre of 6000 to 7000 strong, including 1000 well-trained militants, he defected and surrendered in the army camps. Pillayan (Sivanesathurai Chandrakanthan - former Eastern Provincial Chief Minister) one among them surrendered along with Jayam Master, Sinathambi, Malathi and Regi, were all closely associated with Karuna. They were in charge of political, military, financial and intelligence wings of the eastern administration" (Personal communication, 18 ${ }^{\text {th }}$ March 2016).

This study establishes the five crucial reasons that had caused the defection of Karuna: "(1) The prevalent discriminatory policies of the northern command; (2) The rivalry for power between Pottu Amman (Commander, Intelligent wing) and Karuna; (3) Constant misuse of power and personal ambitions and goals of Karuna; (4) Successful infiltration of the Sri Lankan state; (5) Influenced by the international sentiments" (based on personal communication, Feb, 18 ${ }^{\text {th }}, 2016$ ). Adding to these complications, Karuna was the leader of LTTE's four-member team assembled for negotiations talks with the government where they held six rounds of peace talks between 2002- 2003; defection led to the decline in impression and credibility of the LTTE being the sole negotiator for the Tamil's cause and representatives of initiating unification of homeland and nation (Uyangoda, 2005, p.1).

The Sri Lankan government was swift to capitalise on Karuna's defection and offered him protection and appointing him as a deputy minister twice to fulfil their ambitions and strategies. "Karuna formed his political party named Tamil Makkal Viduthalai Pulikal (TMVP). He promoted the party initially as a military outfit and transforming it into a political party to enter the democratic setting. The rivalry between Karuna and Pillayan for leadership led to the exit of Karuna. He joined the SLFP and promoted to the role of instead of Chairman by the President Rajapaksa" (personal communication, $21^{\text {st }}$ March 2016).

The domination and accommodation of the state and social forces, as explained by Migdal (1994) emphasise the existing social forces incorporated into the state and accommodate them. We can capture this metaphor through the actions of Karuna, who broke from the LTTE and initiated the formation of another social force. When Karuna and the combatants got absorbed by the state, state used them against the LTTE to further weaken them. "The state backed Karuna to form a paramilitary unit (TMVP) that supported the Sri Lankan army in the war against the LTTE. They utilised Karuna to get understand their war strategy, their military base secrets, and high stake secrets that helped the Army to defeat the LTTE. The LTTE was battling on multiple fronts where they are at war with Karuna's faction in a bloody battle to capture the eastern front in the battle of Vaharai. The end of the battle saw deaths of hundreds of militants in Karuna's faction" (Personal communication, 13 $3^{\text {th }}$ February 2016). The state, according to how Migdal proposed, had penetrated the LTTE and broke its eastern wing, bifurcating the LTTE and incorporating the former social force into the state to wage their war.

LTTE's decline in strength was as a direct consequence of Karuna's defection disrupting the peace talks and in the process creating an asymmetrical situation (personal communication, $17^{\text {th }}$ March 2016). A stalemate between the government and the LTTE in deciding who should disarm Karuna's faction showed the LTTE's discomfort in handling their fractured group. Even as the government promised, they never disarmed them as well (De Silva, 2012). The agreement that Karuna puts forward is that the ceasefire agreement will not apply to their group of fighters, as he contests that both his faction and the LTTE are party to the agreement (ICG, 2006, p.9). Rajapaksa rode to power capitalizing the political transition in the state, took all steps available to defeat and dismantle the LTTE. The political wing of the LTTE weakened because of the loss of Anton Balasingham, who passed away because of renal failure on $14^{\text {th }}$ December 2006 and S.P. Tamilchelvan, killed during an air raid on $2^{\text {nd }}$ November 2007. S. P Tamilchelvan considered being an acceptable figure and the face of LTTE.

The government held the rescheduled elections in 2005. The UNP, headed by Wickramasinghe, realised their vision of the future had become a dominant topic of discussion attempted to outbid Mrs. Kumaratunga. Mrs Kumaratunga was quick to realise this ploy by Wickramasinghe and endorsed Rajapaksa as her party's candidate. Rajapaksa was astute in handling the situation by striking personal accord with Janatha Vimukthi Peramuna (JVP) and Jathika Hela Urumaya (JHU) to protect the unitary nature of the state whilst promising to safeguard the party's policies by appeasing all concerned parties. As expected, Kumaratunga's party won both the presidential and parliamentary elections. SLFP's Rajapaksa assumed the head of state after defeating Wickramasinghe, who's considered as the 
underwriter of the peace process by a slim margin. The LTTE played a huge role in Rajapaksa securing his victory. They forbade and prohibited all Tamils in the north-east provinces and their right-wing allies from voting for Wickramasinghe. They enacted this even when Wickramasinghe committed to restarting the peace talks with the interim self-governing authority (ISGA). This Wickramasinghe's victory was hard-fought and at the end, leading to a slim lead in the margin for Rajapaksa who won on the southern vote (Fazil, 2019).

The LTTE engineered the election success of the more hard-line group. They considered this hardliner group in the international media hawkish, Rajapaksa, who affirmed his commitment to brokered peace and negotiated a political settlement with the LTTE. The LTTE found reasons for being excused for negotiations and increased their terrorist activities. This was in the wide public display when they conduct an unprovoked attack against civilians and security personnel. These incidents amplified further when a pregnant suicide bomber managed to injure Army commander Sarath Fonseka and killed the Deputy Army commander, Parami Kulatunga. These events followed by massacring the Sinhala civilians who lived near the de facto border areas. Rajapaksa wasted no time in highlighting these brutal incidents to the international media, turning the sentiments against the LTTE for good (Bandarage, 2009).

The government forces and the LTTE violated ceasefire agreements. They also were not happy with the Norwegian's part as facilitator raising objections to their mediation (Mayilvahanan, 2009). These issues created constant hurdles to the peace process. The government followed the policy to strengthen the armed forces. As expected, the full-scale war got triggered by these small armed skirmishes. Thus, the Eelam war IV erupted and led to the total decline and collapse of the LTTE, leading to their ultimate defeat in the upcoming section. Both parties' guilty of ceasefire violations brought the war upon themselves. The war for peace program started by the government focused on weakening the military capabilities of the LTTE to bring them to the negotiation table. The asymmetrical situation that was existing since late 2006 brought other dimensions to this stalemate where the LTTE was getting weaker. This made the government to rethink their strategy to pursue a different recourse and stop treating the LTTE as an equal party at the table. This hawkish and abrasive behavior to fast-tracked the impending war much sooner than expected, and one that could have got avoided if dialogue been resumed sooner.

The state defeated the LTTE in their Eelam war IV that took place in the eastern province of Sri Lanka in July 2006 and ended in August 2006. The escalation was consistent and detrimental to the peace initiatives. The final nail in the coffin was closing the sluice gates of the Mavilaru reservoir that made the Rajapaksa government (De Silva, 2012), to respond as the livelihoods of 15,000 families lived in the villages controlled by the government depend on it raising the stakes ever higher (Linden, 2009, p. 14). Few view the LTTE's action as a punitive action at the Sri Lankan Muslims and compel them to leave those regions that the Mayilaru channel had served (Mayilvahanan, 2009). The LTTE made their moves calculating to bolster their control over the eastern island regions. Muttur clashes erupted on $2^{\text {nd }}$ August 2006 when the LTTE used that as an opening to launch a heavy artillery attack and gained control of few areas. The military regained them back by $5^{\text {th }}$ August, resulting in at least 150 LTTE cadres, and at least 30 civilians killed. This displaced 25,000 residents. This enabled the military to swoop into the Northern Province to defeat the LTTE in May 2009.

For a while, the LTTE not concerned about the armed forces as they were confident and underestimated the Army's ability to go ahead beyond threshold (Jeyaraj, 2015). To strengthen the security forces of the state, Rajapaksa, the strong-man among statesmen, appointed his brother Gotabaya Rajapaksa (a retired lieutenant Colonel and current President of Sri Lanka) as the Secretary of Defense. The outcome was obvious as Gotabaya displayed a disciplined and pragmatic approach towards result-oriented objectives. He differed from his predecessors so much that he even put forwarded the "Rajapaksa Doctrine". In his own words "By appointing time tested battle hardened commanders, leaders with battlefield experience, modernizing with new weaponry and increased recruitment and training are the hallmark of his new approach" (Asia Pacific Defense Reporter [APDR], 2009).

True to his word and doctrine, Gotabaya appointed competent and experienced commanders who were eventually leading their military arms such as the Sri Lanka Army [SLA], Sri Lanka Navy [SLN] and Sri Lanka Air Force [SLF]. He also indicated that their promotion and recognition will be in line with merit and not seniority. He also anchored cooperation between the armed forces unprecedented laying the action plan to share intelligence and engaging in cooperation. By increasing the defense budget, he could accommodate the numerical expansion of the Army, and enhancing their firepower. He also coordinated his military administrative activities with a large public relations exercise to restore the battered military's image and garner wider public support by galvanizing them through his outreach campaign (APDR, 2009).

The LTTE reeled under the loss of their Eastern province. The Eastern province was their major source for recruitment and losing that region meant that they no longer had complete access to recruit people to bolster their 
strength. This, coupled with the increase in the interception of shipping and funding streams, weakened their organisation and starved off their fighting capabilities. The government forces capitalized this decline to their advantage by advancing into LTTE's hinterland and made significant gains pushing them further into the interior regions. Despite the LTTE confident about their conventional warfare tactics, the Sri Lankan government gained on them using a lot of counterinsurgency tactics and hybrid warfare that the LTTE did not pick these aspects of their war strategy.

The state found that by deploying trained and mobile groups in small teams, they can meet their goals more effectively. They attacked a lot of high-value targets of the LTTE through real-time intelligence and could disrupt or dismantle the LTTE's resupply and communication lines. These groups were specialize in providing correct directions to expose the LTTE to the state's artillery and mortar bombardments. As the joint assault against the LTTE on both the frontal and in-depth meant, the LTTE was always losing ground and freedom to move and getting trapped, exposed and crushed (Layton, 2015).

Deploying small and mobile teams, that are a small part of a larger and distinct Sri Lankan innovation, included deep penetration operations through the Special Forces who operated in tandem with the trained and specialized infantry operations team (SIOT). By increasing the number of Special Forces to 10,000, the Sri Lankan government gained significant and foolproof results in attacking the LTTE leadership targets and in eliminating key leaders and experienced commanders. The timing was crucial to elimination as it caused widespread chaos and mayhem within the rank and file of the LTTE's inflexible hierarchal structure of command. At the height of Eelam war IV, there were approximately 1,500 SIOT troops deployed, and at the end of 2008, the numbers increased to 30,000 (Layton, 2015).

An ex-combatant described that "even as the LTTE never received sophisticated weapons to bolster their defense, they, however, their counter strike and measures involved establishing security barriers and trenches. These measures were nullified and destroyed by the Sri Lankan forces through their coordinated airstrikes. As they used their weapons for purposes such as multi-barrel rocket launchers and artillery they made significant and constant progress into the erstwhile LTTE areas" (personal communication, $18^{\text {th }}$ March 2016).

The Sri Lankan forces, with well-coordinated efforts, and establishing well-trained groups; within a short period, they made the swift process to capture the LTTE at that stage. As the forces advanced, it pushed the LTTE and the civilians into a corner. Taking these progresses in confidence, the Sri Lankan government abrogated the fictional ceasefire negotiated in 2002, in January 2008 along with the Sri Lankan monitoring mission (set up with a group of Scandinavian observers monitoring the ceasefire) on $16^{\text {th }}$ January 2008. This gave the government full control over the battlefield intelligence and information that emerges from it.

As the battle cost significant lives in both sides, the LTTE decided to standing their ground for their more valuable and strategic regions. They started to relent due to the Sri Lankan Army's numerical and sophisticated weaponry to push back the LTTE from their forward positions in the Vanni (Lewis, 2012). This led the Army to ramp up their recruitment based on their earlier successes in the east by cutting levels of desertion. The government strategized their moves to target the LTTE by retaking their coastal areas in the northeast to cut them off their supply lines from India. This enabled them to link the state forces from the south to Jaffna, the government forced their way up to the A32 road taking that connected the north with south which controlled by the government. True to incremental progress, from there they marched ahead to capture the A9 route that links Jaffna with the southern regions for the first time in over two decades. This was slow progress as the LTTE defended these areas but found it difficult to keep it effective as they resorted to the guerrilla army to defend static positions with no match to the Army's gained firepower to protect it (Lewis, 2012).

The Army made brisk progress around January 2009, converting their incremental progress around Kilinochchi. At Paranthan the Army gained on the strategic junction on the A9 to retake the symbolic Elephant Pass, which acts as a guard to the entry of the Peninsula of Jaffna. The $53^{\text {rd }}$ and $54^{\text {th }}$ Division of the Army was threatening the LTTE on their position on Jaffna peninsula. As the LTTE faced attacks on all four corners, the $58^{\text {th }}$ and $57^{\text {th }}$ Divisions drove through the north and northeast town and defended town of Kilinochchi. The LTTE to avoid being encircled abandoned their defense of Kilinochchi in mid-January and retreated further to the interior (Lewis, 2012).

Another Ex-Combatant, while sharing his experience, detailed this period, saying; "The plan by the LTTE was to draw the Sri Lankan forces to the Irranaimaddu Lake that are closer to their position and use bombs to blast the bund, plunging the Sri Lankan forces into the water. This didn't go according to plan when the bomb didn't detonate" (personal communication, $17^{\text {th }}$ March 2016). On the East coast, the $59^{\text {th }}$ Division was advancing up and towards Mullaitivu, further pushing back the LTTE into the smaller territory of Vanni. The government forces narrowed down the ring around LTTE cadres between January and April in 2009. In reality, there was a total 
discard towards the civilian causalities even within the claimed safe zones by the military. On contrary to their claim as the security forces resorted to constant shelling on civilians, hospitals and humanitarian operations. This was highlighted by the independent watch groups to the international countries (Lewis, 2012).

7,000 civilians, estimated by the UN agencies to have perished or killed from January to April 2009 although other estimates suggest that the estimates could be as high as 40,000. This includes the civilians who got killed during the final days of the battle, who kept battling in the last of the No Fire Zones (NFZ) (Lewis, 2012). The LTTE outgunned and outnumbered where their final and total defeat spanned around several days, where the intense fighting took place around the small NFZ in the northern part of the Island. To avoid international pressure, the government toiled hard to make sure and prevent a ceasefire at the closing stages of the war. This could have been intervened by the international community either in preventing a complete and decisive victory over the LTTE and bring them over to eventual closure for good. The government feared another ceasefire pressured by the international leaders that could force them to negotiate with the LTTE to let their leaders surrender.

These initiatives made the government jittery and invigorated fears that the international community will prevent their victory over the LTTE at the last moment. Hence, whilst resisting a wide range of diplomatic pressure, they handled counter diplomacy in advocating their vision to the international community. Meanwhile, they wanted their military to speed up their push to end the LTTE for once and for all. There is much dispute about the accuracy of details emerged from any source about the last days in May 2009, which is subjected to different investigations. As the military took control of the NFZ, they killed most of the LTTE leadership in the process taking around 28,000 civilians into the camps that were setup. 10,000 of the 28,000 claimed to be the LTTE cadres secured in detention facilities (Lewis, 2012). This effective control over the LTTE and civilian movement prevented the possibility of even a low-intensity conflict arising after the crucial battle and it ended military campaign. The government announced the most awaited news to the public on military victory over the LTTE on $18^{\text {th }}$ May 2009 .

\subsection{International Factors}

The Tamil Nadu Government supported the LTTE and empowered them with arms, funds and training. The Union government of India attempted to become an arbitrator and mediator. Their shift in stand came through the murder of former Indian Prime Minister Rajiv Gandhi at the hands of the LTTE. This diluted the Indian sympathy towards their cause and challenge to deal the higher Indian authorities. The LTTE never after could gain any support again from the Indian government as the Congress party as it came back to power in 2004, headed by the widow of Rajiv Gandhi (Hindwan 2011). The LTTE assassinated Rajiv Gandhi while he was campaigning for the 1991 national election. Experts believe that the failure of Indo-Lanka peace accord, Prabhakaran feared that another confrontation with elected Rajiv Gandhi will be detrimental to his cause. Hence he went ahead with the ill-fated decision to murder him (Fazil, 2019).

The failure of the LTTE to garner popular support in Tamil Nadu fueled the doomed decision to end (Fazil, 2019). The LTTE, since then, seen as a terrorist movement proscribed as terrorists and India started backing the Sri Lankan government against the LTTE. This helped the Sri Lankan government to end them both (Nalapat. 2011). Few experts have long argued that the Indian mindset was of a neutral bystander to the Sri Lankan anti-LTTE stand, despite India's open support to Sri Lanka through various veritable sources of evidence. One bunch of evidence showed the gift that Sri Lanka received from India was a Mi-17s besides their offshore patrol vessel of Sukanya class gifted to the Sri Lankan Coast Guard. As seen by all parties, these weapons played a crucial role in many daring missions launched by the Sri Lanka Air Force. The Air force used these in deep penetration operations where the troops always knew they get rescued in the catastrophe's event which bolstered their confidence, enabling them to land stupendous results.

Naval vessels helped the navy target and destroy boats that carry arms in the Indian Ocean, which bought the LTTE to their knees. Sri Lankan Army acknowledged the hand that the Indian vessels had played in destroying even few of their armored personnel carriers. They destroyed over ten floating warehouses; the LTTE had owned which they had used for storing ammunition, arms, and even few of their armored personnel carriers. This concerted attack between 2006 and 2009 broke the back of the Sea Tigers (Gokhale, 2009). The legislature declined the Indian government to help the Sri Lanka Government, coupled with few internal issues. The Sri Lankan government sent this asks during their prime point of the civil war, although India denied them on the ground as those weapons are hostile.

Another regional factor that led to the defeat of the LTTE is when Pakistan tried to capitalise on the vacuum left behind by India, where they calibrated their move to help Sri Lanka in the quest for adding another south Asian partner under its wing. To use this opportunity, the Pakistan government supplanted their chief commissioner of Pakistan, Shehzad Aslam Chaudhry in Sri Lanka, who earlier was an Air Vice-Marshal. They selected him based 
on his experience and involvement in propelling strikes in Baluchistan against their Baluchistan warriors. To stem the revolts, they picked 15 to 17 Air Force officers who had prior experience in quelling rebellions. This core of officers had profound knowledge that helped the Sri Lanka Air Force to draw plans to help their Army with strategic assaults against the LTTE, which turned more brutal. Aside from assisting the Sri Lanka Air Force, Pakistan further inserted itself in the civil war by furnishing more arms and cutting edge military rifles, mines, rockets and launchers and other hosts of hostile weapons that India earlier denied supplying. Hence, we can say that Pakistan's deliberate insertion to be a party to this civil war for Sri Lanka along with China filling the vacuum left by India seen as a key regional factor that led to the defeat of the LTTE.

In various parts of the world at the end of the $20^{\text {th }}$ century, militant social forces faced multiple levels of resistance and challenges. They proscribed many militant organizations as terrorists' organizations. The LTTE was not only being challenged by the state of Sri Lanka, but they were also facing setbacks in the international arena. As the situation declined, the LTTE crumbled and led to their elimination at the hands of the Sri Lankan Army in 2009. While interpreting his experience, Mayilvaganan (2009. p.25) states that the GWOT (Global war on terror) and allied developments changed the international sentiments against the insurgent groups and the Sri Lankan Special Forces which dominated the LTTE since 2006 too seen as efforts to seek a solution through armed and violent activities will no longer be a workable solution.

The United Nations (UN) declaration adopted in 1994 on "Measure to end International Terrorism". Two years later an Ad Hoc committee got formed on terrorism. This declaration got legitimized further after the 9/11 gaining a lot of international momentum. The international community recognized a need for a broader consensus on fighting terrorism through initiatives such as the GWOT. The UN Security Council Resolution (N0.1373) on counter-terrorism adopted after the horrifying 9/11 incident (Mayilvaganan, 2009). The resolution calls for all states to prevent, suppress and eradicate all forms of terrorism and terrorist activities on their soil through various social and financial curbs. Besides these curbs, the resolution calls to criminalize fund collection activities supporting these terrorist acts and organisations. The resolution additionally recommends freezing the funds and financial assets and other economical sources of those people, who can plan, commit, try to commit or take part or help terrorist activities (United Nations Security Council [UNSC], 2001).

The Advocates for peace from the international community encouraged both parties to push for peace by pledging a resolution to the conflict by offering autonomy in the Northern and Eastern Tamil areas. Although around the same time, they designated the LTTE as a terrorist organisation under the GWOT, after the September 9/11 attacks. The USA banned the LTTE under the legislation for Anti-terrorism (1997), the UK in 2001, and India in 1991. Other countries like Australia, EU, and Canada joined the league and banned any fundraising activities (Zissis, 2006; Washington Post, 2006; BBC 2006; Nadarajah \& Sriskandarajah, 2005; Mayilvaganan, 2009). The number of peace observers decimated to just three EU members when the LTTE suspended by the countries like Denmark, Finland and Sweden on $1^{\text {st }}$ September 2006. It motivated the pro-Tamil people to join rank and file in helping the organisation through their international network. But by freezing of pro-LTTE bank accounts prevented close to a billion US dollars, the Tamil Diaspora raised it in the west through a lot of fundraising activities. This curb stopped the funds in reaching the LTTE's accounts, curbing them in procuring key arms and ammunitions that led them to challenge and stand toe to toe with Sri Lanka and its military. Through GWOT, the United States and its allies from the west curbed the LTTE. Even the Sri Lankan government was not spared from sanctions either when the US blocked sales of arms and ammunition to Sri Lanka in 2007 due to human rights violations. But, the US misread its Asian counterparts and the Asian geopolitics, since Asian politics played a crucial role in the defeat of the LTTE during the last few years of the war.

China filled this vacuum which pounced on the opportunity to raise its bilateral aid to Sri Lanka by five times during 2007 and 2008 and Colombo was the number one recipient of Chinese foreign aid. The aid increased a billion dollars, Sri Lanka used it to buy arms from both China and Pakistan (Parasram, 2012). Even Russia and Iran chipped in to offer military help by offering expert consultations. This joint effort led to Sri Lankan state victory over the LTTE within a short period. States that face secessionist movements in their state have chipped in and filled the gap in military equipment supply. Countries like China, Russia and Israel supplied tanks, jets and Radars (Wezeman 2009 cited in Parasram, 2012). Sri Lanka was careful in utilizing the help offered and ensured they had China to back them in the Security Council to veto any adverse decisions. These reasons too played into the Sri Lankan military victory over the rebels and led the LTTE to its eventual demise.

\section{Conclusion}

By reviewing the historical relationships between the state-society and their rivalries from the post-independence period, this paper aimed to preset the growth of LTTE as a vigorous social force tracing their journey into 
challenging the image and actual practice of the unitary model of the Sri Lankan state. Their uprising weakened the actual practice of Sri Lankan state, and both parties entered a phase of negotiations when both matched each other leading to a stalemate. The LTTE captured a large part of the country's north and eastern region being demarcated by the ceasefire agreement signed in 2002. The ceasefire agreement itself was in danger of collapse as the Sri Lankan government and the LTTE were playing brinkmanship, renewing their civil war. The analysis discusses on how the war got renewed, in the paper, show how the LTTE failed because of national and international factors that contributed to the demise of the LTTE that attempted to set up a separate Eelam state for the Tamil minority in the Island of Sri Lanka.

\section{References}

Asia Pacific Defence Reporter [APDR]. (2009). How Sri Lanka won the unwinnable war. Retrieved from https://www.asiapacificdefencereporter.com/articles/36/How-Sri-Lanka-Won-the-Unwinnable-War

Bandarage, A. (2009). The separatist conflict in Sri Lanka: Terrorism, ethnicity, political economy. Colombo, Sri Lanka: VijithaYapa. https://doi.org/10.4324/9780203886311

BBC. (2006, July 21). Tigers reject EU monitors appeal. Retrieved from http://news.bbc.co.uk/2/hi/south_asia/5203216.stm

De Silva, K. M. (2012). Sri Lanka and the defeat of the LTTE. Colombo, Sri Lanka: VijithaYapa Publications. https://doi.org/10.1215/9780822394051-083

De Votta, N. (2009). The liberation tigers of Tamil Eelam and the lost quest for separatism in Sri Lanka. Asian Survey, 49(6), 1021-1051. https://doi.org/10.1525/as.2009.49.6.1021

Fazil, M. M. (2019). State-minority contestations in post-colonial Sri Lanka. Journal of Educational and Social Research, 9(4), 157. https://doi.org/10.2478/jesr-2019-0065

Fazil, M. M. (2016). Norway \& Japan in peace negotiations in Sri Lankan ethnic conflict: A new phase of mediatory roles. Germany: LAP LAMBERT Academic Publishing.

Fowsar, M. A. M. (2020). Third-party mediation in Sri Lanka's peace attempts: A study on the role of Norwegian mediation. Journal of Politics and Law, 13(3), 30-37. https://doi.org/10.5539/jpl.v13n3p30

Gokhale, N. A. (2009). Excepted from Sri Lanka: From war to peace. New Delhi: HarAnand Publishers.

Hashim, A. S. (2013). Eelam war IV: A military analysis. In When counterinsurgency wins: Sri Lanka's defeat of the Tamil tigers. University of Pennsylvania Press. https://doi.org/10.9783/9780812206487.132

Hindwan, T. (2011). Defeat of LTTE: A lesson in COIN operation. (Research Report, Air Command and Staff College, Air University). Retrieved from https://apps.dtic.mil/dtic/tr/fulltext/u2/1019061.pdf

International Crisis Group [ICG]. (2006). Sri Lanka: The failure of the peace process. Asia Report No. 6.

International Crisis Group [ICG]. (2010a). The Sri Lankan Tamil diaspora after the LTTE. Asia Report No.186.

International Crisis Group [ICG]. (2010b). War crimes in Sri Lanka. Asia Report No. 191.

Jeyaraj, D. (2015, December 18). TNA leader Sampanthan, Chief Minister Wigneswaran and the crisis of Tamil political leadership. Retrieved from http://dbsjeyaraj.com/dbsj/archives/44401

Layton, P. (2015, April 9). How Sri Lanka won the war: Lessons in strategy from an overlooked victory. The Diplomat. Retrieved from http://thediplomat.com/2015/04/how-sri-lanka-won-the-war/

Lewis, D. (2012). Counterinsurgency in Sri Lanka: A successful model? In P. B. Rich, \& I. Duyvesteyn (Eds.), The Routledge handbook of insurgency and counterinsurgency. Abingdon, Oxon: Routledge.

Linden, J. (2009). After the tigers: Moving beyond the legacy of violence in Sri Lanka. Michigan Journal of Public Affairs, 6(14).

Mayilvaganan, M. (2009). Is it endgame for LTTE? Strategic Analysis, 33(1), 25-39. https://doi.org/10.1080/09700160802518536

Nadarajah, S., \& Sriskandarajah, D. (2005). Liberation struggle or terrorism? The politics of naming the LTTE. Third World Quarterly, 26(1), 87-100. https://doi.org/10.1080/0143659042000322928

Nalapat, M. (2011). Defeating terrorism - Why the Tamil tigers lost Eelam and how Sri Lanka won the war. Retrieved from http://www.jinsa.org/publications/global-briefing/defeating-terrorism-why-tamil-tigers-losteelamand-how-sri-lanka-won-war

Parasram, A. (2012). Erasing Tamil Eelam: De/Re territorialisation in the global war on terror. Geopolitics, 17(4), 
903-925. https://doi.org/10.1080/14650045.2012.654531

United Nations Security Council [UNSC]. (2001, September 28). Security Council unanimously adopts wideranging anti-terrorism resolution: Calls for suppressing financing, improving international cooperation. Retrieved from http://www.un.org/press/en/2001/sc7158.doc.htm

Uyangoda, J. (2005). Ethnic conflict, ethnic imagination and democratic alternatives for Sri Lanka. Futures, 37(9), 959-988. https://doi.org/10.1016/j.futures.2005.01.018

Washington Post. (2006, June 8). Sri Lanka talks with rebels collapse. Retrieved from http://www.washingtonpost.com/wp-dyn/content/article/2006/06/08/AR2006060801508.html

Wezeman, S. (2009). Arms transfers to Asia and Oceania. Stockholm International Peace Research Institute Background Paper. Retrieved from http://books.sipri.org/files/misc/SIPRIBP0910a.pdf

Zissis, C. (2006). The Sri Lankan conflict. USA: Council of Foreign Relations. Retrieved from http://sangam.org/taraki/articles/2006/09-13_Conflict.php?uid=193..\&print=sangam

\section{Copyrights}

Copyright for this article is retained by the author(s), with first publication rights granted to the journal.

This is an open-access article distributed under the terms and conditions of the Creative Commons Attribution license (http://creativecommons.org/licenses/by/4.0/). 